\title{
○鉿、隆男（上飯田第一病院）磯匐愿三（名古屋逓信病院） 月山昌夫（東海聥信病浣）
}

目的：音響伈理学的に求めた 2 音抑制の 1)抑制音レベルが被抑制音レベルよりも常に10 $\mathrm{B}$ 以上高くないと抑制は出現しない。2)抑制音の抑制に対するレべル効果は非線形である。 (3)㳩制は被抑制音の振幅が単純に隇少するにすぎないという3つの仮定が常に成立するか どうかを検討するために次の実験を行った。

方法：抑制音と被抑制音には帯域幅 $200 \mathrm{~Hz}$ の帯域雑音を用い，ともに持続時間は600m ,

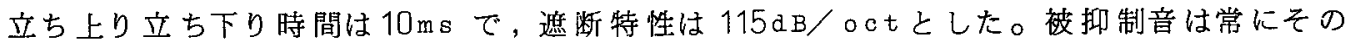
中心周波数を $3 \mathrm{kHz}$ とした。信号音の持続時間は $15 \mathrm{~ms}$, 立ち上り立ち下り時間は $5 \mathrm{~ms}$ ， 遮断特性 $144 \mathrm{~dB} / \mathrm{oct}$ のフィルタを通過させ，常に時間間隔０の forward maskingでの遮 蔽域值を測定した。

実験 I：信号音周波数を常に $3 \mathrm{kHz}$ に固定し，抑制音の中心周波数の関数としての遮蔽域 值を求めた。パラメータは破抑制音のレベルで30,20,10, 0, - $10 \mathrm{~dB} \mathrm{SPL} \mathrm{(dB/Hz)とし，}$ それぞれの被抑制音レベルに対して抑制音レベルは40〜-15 dB SPL ( dB/Hz)で $5 \mathrm{~dB}$ ステ ップの可変とした。

実験 II : 抑制音の中心周波数をパラメータとした場合の遮蔽域徂を信号音周波数の関数と して, 被抑制音, 抑制音および被抑制音十抑制音の場合について求め，抑制の周波数分布 パターンを検討した。

成績と考察 : 実験 I

1) 㧕制 音が高域側の場合

(1) 被湖制音レベルが $30 \mathrm{~dB}$ の場合には $3 \mathrm{~dB}$ のマスキング加算が起こる。すなわち, 信号 音周波数の慜接臨界帯域ではマスキング加算は現われないが, さらに次の䠦界带域で加算 が起こる。

(2)被聊制音レベルが $20 \mathrm{~dB}$ と $10 \mathrm{~dB}$ では抑制が現われ，㧕制音のレベル減少とともに隇 少するが，被抑制音レベルよりも低い抑制音レベルでも抑制が出現する。抑制量は被抑制 音 $20 \mathrm{~dB}$ の場合に大きい(困 1)。

(3)被抑制音レベルが OdB の場合には抑制音レベルが $25 \mathrm{~dB}$ 以上では㧕制は現われないが, 20〜0 dB では出現し，それ以下では消失する。ただし，出現した抑制量も少ない。被御 制音レベルー10 d B では抑制は全く出現しない。

(4) 抑制音レベルが低くなるとともに最大抑制 量を起こす抑制音周波数は信号音周波数に近づ く。この関係は被抑制音レベルが低くなっても 大きく変らない。

2)抑制音が低域測の場合

(1) 抑制音レベルが $40 \mathrm{~dB}$ の場合には, 被抑制 音のレベルが $30 \mathrm{~dB}$ でも20 dBでも最大抑制量 はほほ等しい。

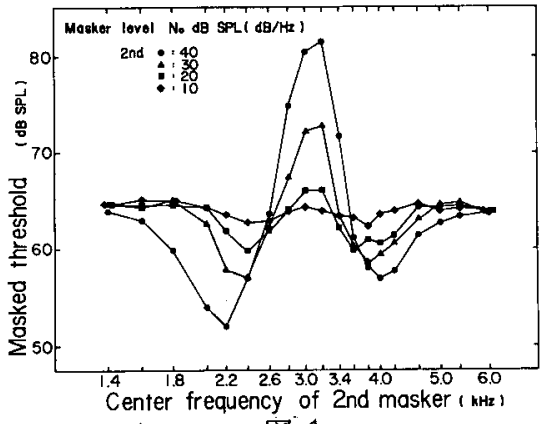

図 1 
(2)被抑制音レベルが30,20dBでは，抑制音とのレベルが等しくとも抑制は出現する。ただ し, 抑制量は前者で多い。

(3)被抑制音レベルがさらに低くなると，抑制音レベルが高くないと抑制は出現しない。

(4) 抑制音レベルが低くなるほど, 最大抑制を起こす抑制音周波数は信号音周波数に近づ く。また，被抑制音レベルが低くなるほど，最大抑制を起こす抑制音周波数は信号音周波 数から離れる。

以上のことは，抑制は被抑制音の総合レベルが域值上 $20 \mathrm{~d} \mathrm{~B}$ 以上なければ起こらないこ と，抑制音は被抑制音の臨界带域内の成分に対して抑制を起こすこと，また，低域抑制は 抑制域值が高く，抑制帯域が広く，高域抑制は㧕制域値が低く，抑制帯域の狭いことを示 す。

\section{実 験 II}

(1)抑制音が被抑制音より 2 臨界帯域以上離れた場合の抑制の周波数分布は被抑制音によ るマスキングパターンの低域勾配に現われる(図 2 )。

(2)抑制音が被抑制音より 2 臨界带域離れた場合に，抑制は被抑制音の中心周波数で最大 となり，その量は 10〜 $13 \mathrm{~d}$ Bに達し, 抑制の周波数分布は被抑制音のマスキングパターン の尖端部と一致する(図 3)。

(3)抑制音が被抑制音より 2 臨界带域以内に入ると, 抑制の周波数分布は被抑制音のマ之 キングパターンの高域勾配に移動する(図 4)

(4)抑制音が被卯制音より低域側にある場合の方が抑制量も大きく，抑制の周波数分布も 広い。

以上のことは，抑制の周波数の位置により，ある周波数の抑制が他の周波数範囲の抑制 より大きいことを示す。すなわち，抑制はただ単に被抑制音のラウドネス減少に関与する だけでなく， sharpeningにも関与し，抑制の周波数分布は比較的狭いことを示す。

結論 1) 抑制は抑制音レベルが被抑制音レベルより低くとも起こる。

2)抑制は, 被抑制音の総合レベルが域值上 $20 \mathrm{~dB}$ 以上 $(\mathrm{O} \mathrm{dB} / \mathrm{Hz})$ で起こり, 抑制音レベ ルに対して線形増大する。

3) 抑制は単純な振幅減少ではなく，抑制の周波数分布は抑制音の周波数位置によって変 るが，最大抑制量が現われるのは抑制音周波数が被抑制音周波数より2 臨界带域離れた場

合である。

図 2

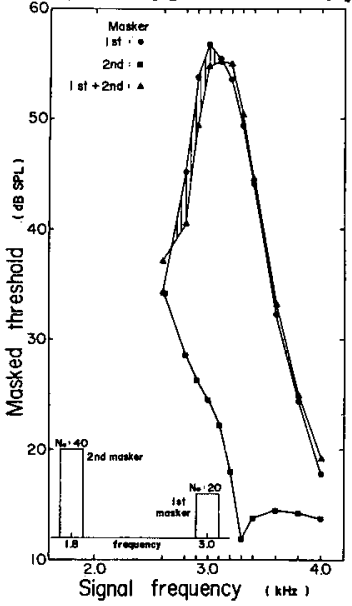

図3

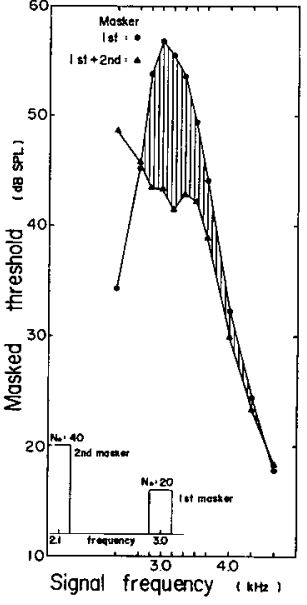

区 4

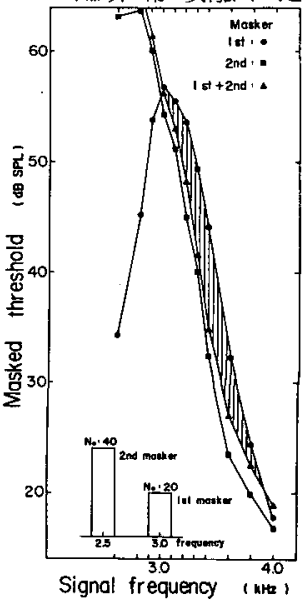

